\title{
252 視野制限のある場における多方向デジタルスペックル法の開発
}

\section{Development of the multi projection digital speckleglam in limited view angle}

加藤木 幸夫 (茨城工業高等専門学校 機械電子制御専攻) 池田 耕（茨城工業高等専門学校）

\begin{abstract}
Nowadays, the alternative fuel for the engine is required. Di-methyl-ether(DME) is one of alternative, which thought to be cheap, clean and can burn in normal diesel engine. Property of DME inside the engine is not examined. Therefore technique to measure the DME splay inside engine is required. Recently, the digital speckle photography, which is able to measure refractive indices quantitatively, was developed. Inside engine, temperature and pressure tend to be high; therefore to measure the refractive indices inside engine, measuring window should be small enough to endure these environments. In this study the technique to measure multi angel refractive indices in limited view angle was developed using digital speckle photography. The technique was applied to measure candle flame. The temperature distribution was observed, showing the effectiveness method.
\end{abstract}

\section{Keywords: DME, Digital speckle photography, limited view}

\section{1 緒言}

近年、車などからの排出ガスによる地球温暖化が地球規模 の問題となっている。また、原油は限りある地球の資源であ り、将来枯渴する。それゆえ、現在原油由来の燃料に代わる クリーンな代替然料が必要とされている。その代替然料の一 つとして DME（Di-methe y l-ether）があり、低公害の燃料 として近年注目されている。DME は天然ガスを元に精製さ れ、ディーゼルエンジン内で圧縮着火が可能である。しかし、 一般に DME の高圧下での状態などの特性はまた知られてい ないっそこで、DME のエンジン内の挙動をしるためには、 高圧・高温下での液体や気体の分布を定量的に測定する必要 がある。このような測定には過去シュリーレン法、シャドウ グラフィ法や干涉法のような光学的密度測定技術が使用され、 流体の流れの変化や屈折率の変化を測定する基本であった。 しかし、燃焼システムへの適用となると、シュリーレン・シ ヤドウグラフでは、定量性にかけ、一方で干涉計ではシステ ムの複雑さが問題となる。そこで、本研究では近年発達して きた定量的屈折率分布計測手法であるディジタルスペックル フォトグラフィ (DSP) 法を利用する。

DSP 法は従来のスペックルフォトグラフィ法と違い、スペ ックルの移動量の計算を光学系をしようせずに電子計算機上 で行う。そのため、光学系が簡便になることが一つの利点で ある。さらに、密度勾配を利用した手法であるため、感度の 調整が比較的簡便であり、干涉法では困難である急勾配な分
布に関しても定量測定可能である利点を持つ。このような利 点から、エンジン内の噴霧のように気相・液層が混在寸る場 の測定に力を発揮する。また、通常エンジンでは燃焼室形状 を変え、燃料の動きを 3 次元的に変動させることにより出力、 排気等の条件を変動させる。そえれゆえに、測定は 3 次元的 なものである要請がある。そこで、本研究ではエンジン内の ように限られた条件下において 3 次元計測が可能になる DSP 法の手法を開発を目指寸。

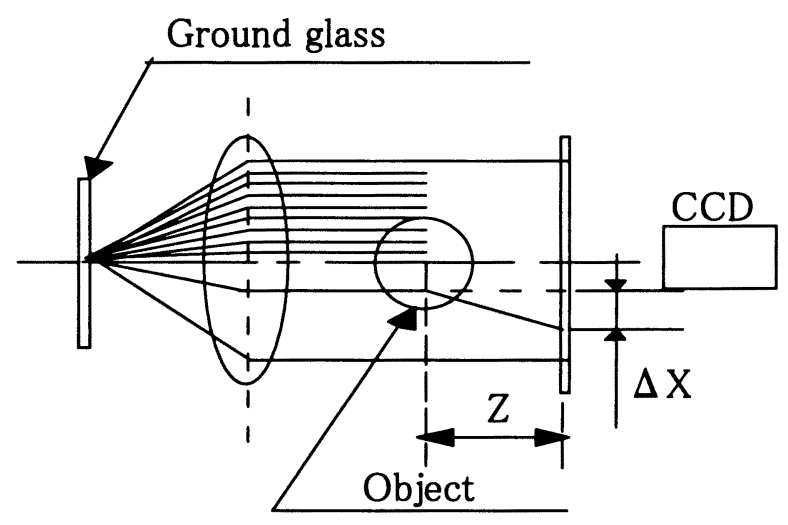

Figure 1: Schematic view of the DSP

\section{3 実験原理}

デジタルスペックルフォトグラフィ法では Fig. 1 に示すよう にスペックルの移動量 $\triangle \mathrm{X}$ を測定する。スペックルは、式 (1) 
に示寸ように移動量 $\Delta \mathrm{X}$ と物体からスクリーンまでの距離 $\mathrm{Z}$ から相互相関法により屈折率 $\mathrm{n}$ を求めることができる。

$\mathrm{Z}$ は、物体とスクリーンからの距離であり、nは物体の 屈折率、 $\Delta \mathrm{X}$ はスペックルの変位である。デジタルスペック

$$
\frac{\Delta X}{Z}=\int \frac{\partial n}{\partial x} d z=\frac{\partial}{\partial x} \int n d z-(1)
$$

ルフォトグラフィは一本のレーザ光で簡単なシステムで測定 することが可能である。

上記の式より、一方向のデータより得られるのは実際の分 布を経路積分した值にしかならない。しかし、このような情 報が得られる場合、複数方向からの情報を得ることができれ ば3 次元の分布にコンピュータトモグラフィ手法をもちいて 計算可能である。ところが、エンジンなどの内部を測定する 際に、燃焼システムは高温・高圧である。それゆえ測定空な どの測定領域が限られてくる。一般には測定に使用される装 置の測定空は対面にあることが多いが、このような測定空で は得られる測定方向が 1 万向に限定される。そこで、本論で は図 2 に示すようなミラーと測定空二つで 2 方向の情報が得 られるレイアウトを提案する。ある程度の大きさの測定空を 二つ置くことによって制限された測定空を有効に利用するこ とができると考えらシステムを考えた場合、一本のレーザ光 で測定しミラーをある程度の角度をつけることによって一度 に2方向の情報を得る事が可能である。

\section{4 実験方法}

実験に用いた光学系を Fig. 2 に示す。まず拡大平行光を作 り、すりガラス (Ground glass) に通してスペックルパター ンを作成する。次に、測定物体（この実験ではろうそく）に スペックルを通し、CCD カメラに二つの画像を撮り込む。一 つは参照パターンともうひとつは屈折率変化によるスペック ルパターンが移動したとき画像とする。実験の際のパラメー

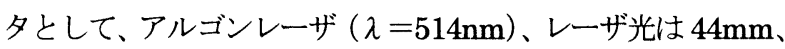
ろうそくの位置は中心より $7 \mathrm{~mm}$ の場所に置く。物体（ろう そく) とスクリーンとの距離は上方が $554 \mathrm{~mm}$ 、下方が $472 \mathrm{~mm}_{\text {。 }}$ 以上の条件の中、測定を行った。

\section{5 実験結果}

実験結果を Fig.4 に示す。まず、はじめにスペックルの移 動べクトルをもとに、ろうそくの炎を 2 次元形状に再構築す る。炎の勾配量は、微分值に相当するため単純に積分するこ とによって炎の形状を逆算することができる。しかしながら、 計測領域が有限であるために、積分に境界值を与えなければ ならず、実際の計測においては炎の形状を求めることができ ない。そこで本実験ではランダム収束法を用いて炎の再構築 を行った。乱数によって任意の点を選択し、この点における 傾きが計測值 (ベクトル) と一致するように平面の高さを修 正していく。このプロセスを繰り返すことによって炎の形状 の高さの分布を正しい值に収束させていくことができる（一

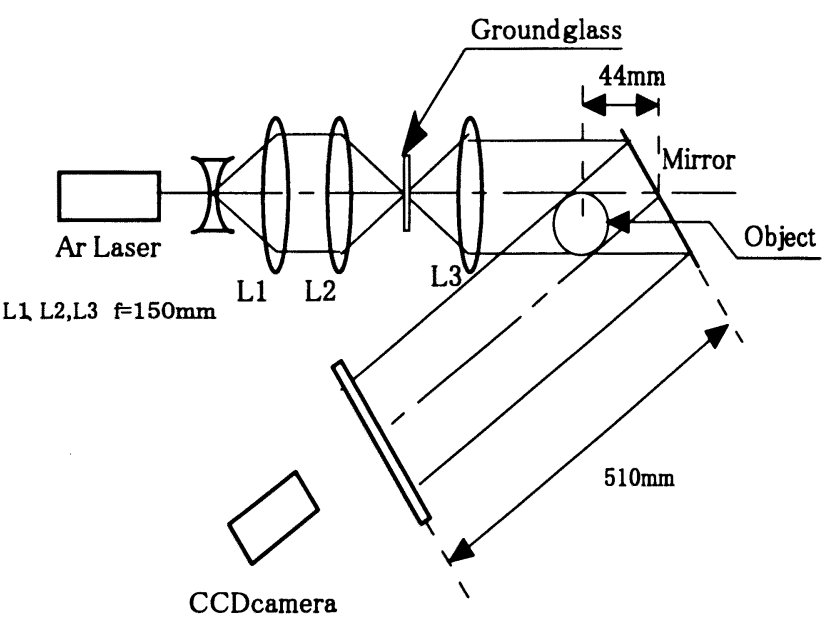

Figure 2: Optical layout of the experiment

種のモンテカルロ積分)。Fig.5 はろうそくの 2 方向を解析し た結果である。1方向の結果にも示されるように Fig.5には、 2 方向のろうそくの炎の形状が確認できる。2 方向の情報が オーバーラップする領域での情報には若干の問題があるもの のそれぞれの積分值がよくあらわれていることがわかる。

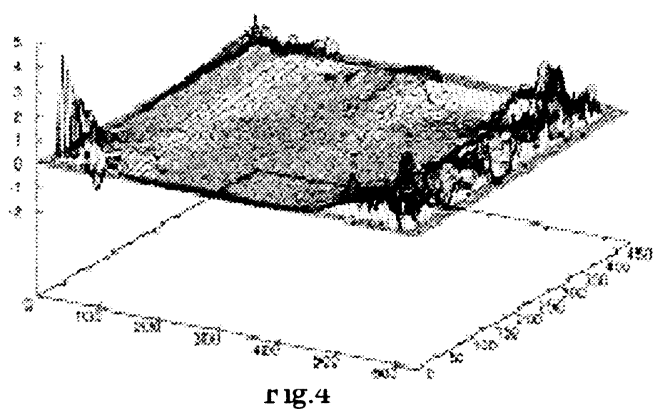

5 結論

実験を行ってろうそくの炎の 2 方向のデータが得られた。 しかし、2 次元の情報を再構筑したため定量的な結果を得る ことができなかった炎の全体の形状を 3 次元構筑するために は、多方向のデータが必要になる。この手法を奏際の計測に 適用するにはまだ大幅に改善がすることが必要である。

参考文献

(1) 「 Density field measurement by digital laser speckle photography J M.Kawahashi and H.Hirahara

(2) 「Visualization vortical structures by density gradient detection」 Richard,H and Raffel,M

(3) SSpeckle photography of spatially extended refractive-index fields」 U.Wemekinck and W.Merzkirch 